Ekonomia - Wroclaw Economic Review 23/2 (2017)

Acta Universitatis Wratislaviensis

No 3770

DOI: 10.19195/2084-4093.23.2.3

\author{
Mateusz Machaj \\ Uniwersytet Wrocławski \\ mateusz.machaj@uwr.edu.pl
}

\title{
Imperialne interpretacje rewolucji przemysłowej w Anglii
}

Artykuł nadesłany: 10 grudnia 2016 r.; artykuł zaakceptowany: 20 lutego 2017 r.

JEL Classification: N00, N13, O4

Keywords: industrial revolution, interventionism, economic growth

\begin{abstract}
Imperialistic Interpretations of the Industrial Revolution in England

The article briefly addresses some of the mistaken interpretations of the Industrial Revolution. In each session the following themes are shortly related to the industrial revolution: aristocracy, slavery, banking system and limited liability, public debt, navigation acts, foreign trade and colonies, and public debt. Last section points to the essence of the industrial revolution, which boils down to innovation implementations, beneficial to the massive consumers.
\end{abstract}

\section{Wstęp}

Rewolucja przemysłowa jest symbolem gwałtownego przełomu w filozofii gospodarowania, który dokonał się w osiemnastowiecznej gospodarce Wielkiej Brytanii. Fakt ten stał się początkiem nowej ery w dziejach ludzkości, którą Joel Mokyr trafnie określa mianem ,gospodarki oświeconej”. W wyniku owego ekonomicznego oświecenia (w szczególności społeczności „zachodnich”) nastała największa w historii aprobata dla idei aktywnego przedsiębiorczego działania.

Wśród niektórych autorów pojawiają się sugestie, jakoby rewolucja nie mogła się dokonać bez wspierających ją ciemnych stron imperium brytyjskiego. Chodzi o takie kontrowersyjne działalności, jak niewolnictwo, kolonializm, imperializm, uprzywilejowanie warstw arystokratycznych, merkantylizm czy inflacjonizm w systemie pieniężnym. Jak zostanie wykazane, istnieją względnie satysfakcjonujące historyczne opracowania, które łatwo podają te tezy w wątpli- 
wość (mimo ograniczonych i niejednoznacznych danych). Okazuje się bowiem, że gigantyczny wzrost produktywności, który się dokonał w Wielkiej Brytanii, był przede wszystkim skutkiem podstawowego i niekwestionowanego źródła trwałego wzrostu gospodarczego: akumulacji przedsiębiorczych innowacji.

\section{Rewolucja przemysłowa a klasy społeczne}

Każdy system polityczny ma tendencję do stabilizacji. W każdym systemie dochodzi też do społecznej stratyfikacji: niektórzy ludzie uzyskują pozycję bardziej uprzywilejowaną od innych. Wyraża się to prestiżem, władzą i pieniędzmi, które $\mathrm{w}$ okresie preindustrialnym przypisane były przede wszystkim brytyjskiej klasie arystokratycznej, posiadającej oprócz majątków prerogatywy do działania. Niejednokrotnie zaszczyty te zostały zdobyte w sposób stojący w sprzeczności z rozmaitymi koncepcjami etycznymi. Przejście na gospodarkę rynkową charakteryzuje się tym, że niektóre grupy społeczne mogą uprzywilejowanie czerpać z owoców transformacji dzięki pozycji odziedziczonej z epoki poprzedzającej. Do pewnego stopnia zasadne jest w tym miejscu metaforyczne pojęcie ,grzechu pierworodnego", który oznaczał brzemienny ciężar z przeszłości, rzucający nieraz cień na słuszność teraźniejszych zmian.

Pytanie, które możemy w tym kontekście postawić, brzmi: kto właściwie „zrobił” rewolucję przemysłową? Czy byli to arystokraci i warstwy wyższe? Czy było to ziemiaństwo? Skąd właściwie wywodzili się pierwsi industrialiści?

Odpowiedzi na nie dostarcza opracowanie Françoisa Crouzeta, który prześledził historię gospodarczą związaną z ponad trzystoma największymi przemysłowcami w Wielkiej Brytanii w latach 1750-1850. Podzielił ich na cztery umowne klasy: najwyższą, średnią wyższą, średnią niższą oraz klasę niższą. Badania przeprowadził zarówno w oparciu o bezpośrednią sytuację przemysłowców, jak i o to, z jakich rodzin się wywodzili. Poniżej tabelka, która obrazuje wnioski dotyczące pochodzenia samych przemysłowców (Crouzet 2008, s. 149-150):

Tabela 1. Podział 316 wielkich przemysłowców na klasy

\begin{tabular}{l|r|c}
\hline \multicolumn{1}{c|}{ Podział na klasy } & Liczba & Udział w całości [\%] \\
\hline Klasa 1: lordostwo, szlachta, oficerowie & 8 & \multicolumn{1}{c}{2,50} \\
\hline Klasa 2: prawnicy, lekarze, handlarze, fabrykanci, bankierzy etc. & 142 & 44,90 \\
\hline Klasa 3: rolnicy, farmerzy, sklepikarze etc. & 85 & 26,80 \\
\hline Klasa 4: klasa robotnicza, przeszkolona i nieprzeszkolona & 31 & 9,80 \\
\hline Nieznani & 50 & 15,80 \\
\hline
\end{tabular}

Z powyższych danych łatwo wyciągnąć wniosek, że rewolucja przemysłowa z pewnością $n$ i e była przemianą napędzaną działaniami arystokracji i klas wyższych. Rewolucja przemysłowa stanowiła dzieło kreatywnych przedsiębior- 
ców, którzy wprowadzali do masowej produkcji przełomowe innowacje zwiększające produktywność. Czy ci kreatywni przedsiębiorcy byli werbowani z klas najwyższych? Najwyraźniej nie. Część z nich być może, ale jak pokazują powyższe dane, dotyczy to mniej znaczącego odsetka.

Oczywiście trudno jednocześnie twierdzić, że rewolucja przemysłowa była społecznie „losowa” lub że werbowanie kreatorów było całkowicie przypadkowe (zresztą rynkowe sukcesy nigdy nie są losowe niczym w kasynie). $Z$ pewnością nie można jednak sądzić, że była napędzana przez klasę arystokratyczną. $Z$ opisu Crouzeta wynika raczej, że arystokracja w dużej mierze przespała rewolucję przemysłową (choć i tak na niej skorzystała — podobnie jak reszta społeczeństwa). Przespała w tym znaczeniu, że obok niej w społeczeństwie wyrosła zupełnie nowa przedsiębiorcza klasa.

\section{Rewolucja przemysłowa a niewolnictwo}

Jednym z często powtarzanych argumentów o rewolucji przemysłowej jest sugestia, jakoby niezbędny kapitał do finansowania rewolucji przemysłowej pochodził z handlu niewolnikami. Wielka Brytania faktycznie wzbogaciła się w czasie, gdy pozostałe kraje doświadczały od niej cierpień, w tym niewolnictwa. Jednakże w wątpliwość należy podać dopowiedzianą i założoną przyczynowość obydwu zjawisk. O ile rzeczywiście w imperium istniał przemysł niewolniczy, o tyle należy mieć uzasadnione zastrzeżenia dotyczące tego, czy zadawanie krzywdy innym krajom może doprowadzić do kilkudziesięciokrotnego wzrostu produkcji per capita, tak jak miało to miejsce w Wielkiej Brytanii ${ }^{1}$.

Przyjrzymy się zatem, jak duży był udział niewolnictwa w gospodarce Wielkiej Brytanii.

Argument o roli sektora niewolniczego dla akumulacji kapitału pochodzi z opracowania Erica Williamsa, który zyskał na nim sławę, a następnie został pierwszym premierem Trynidadu-Tobago. Sporą rolę w tym odegrało właśnie opracowanie Capitalism and Slavery, w którym postawił dwie tezy. Pierwszą, że rewolucja przemysłowa została sfinansowana niewolnictwem. Drugą, że rewolucja przemysłowa doprowadziła do wykształcenia się konkurencyjnego rynku pracy, sprzecznego z ideą niewolnictwa - w związku z tym opłacalne stało się jego zniesienie i zdecydowały o tym lobbystyczne rozgrywki. Druga teza z pewnością ma w sobie jakąś rację, ponieważ rozwijającej się gospodarce rynkowej służy konkurencja o pracownika. Jakkolwiek historycy podali w wątpliwość tę

1 Pozwólmy sobie w tym miejscu na dwie dygresje. Po pierwsze, w rozumowaniu istnieje oczywisty historyczny problem: skoro niewolnictwo istniało (i nadal istnieje w niektórych miejscach) tysiące lat, to czemu dopiero w Wielkiej Brytanii doszło do eksponencjalnego wzrostu gospodarczego? Po drugie, pomnożenie kapitału wymaga stworzenia czegoś produktywnego — nawet jeśli został skradziony, to mnożenie kapitału dokonuje się nie przez akt kradzieży, lecz rozsądnej alokacji. 
tezę, wskazując, że klasy przedsiębiorców nie miały silnej lobbystycznej pozycji u władzy, w związku z czym o przełomie zdecydowały przede wszystkim czynniki ideologiczne (Anstey 1968, s. 319).

Co do tezy pierwszej i dla nas interesującej przyjrzyjmy się szacunkom przeprowadzonym przez Stanleya Engermana (1972, s. 440):

Tabela 2. Zyski z niewolnictwa i ich udział w dochodzie narodowym Wielkiej Brytanii (funty)

\begin{tabular}{c|c|c|c|c}
\hline & $\begin{array}{c}\text { Zyski całkowite } \\
\text { (tys.) }\end{array}$ & $\begin{array}{c}\text { Seria } \\
\text { alternatywna }\end{array}$ & $\begin{array}{c}\text { Dochód narodowy } \\
\text { (mil.) }\end{array}$ & $\begin{array}{c}\text { Udział zysków } \\
\text { w DN [\%] }\end{array}$ \\
\hline 1688 & 178,6 & & 48 & 3,70 \\
\hline 1710 & 110 & & 57,4 & 1,90 \\
\hline 1730 & 55 & & 46,6 & 1,20 \\
\hline 1750 & 214,6 & & 51,7 & 4,20 \\
\hline 1770 & 342 & 44,2 & $62,8[130]$ & $5,4[2,6]$ \\
\hline 1800 & & 103,4 & {$[232]$} & {$[0,40]$} \\
\hline
\end{tabular}

Pierwsze dwie kolumny to szacunki zysków z niewolnictwa według dwóch różnych źródeł. Trzecia kolumna to szacunki dochodu narodowego w oparciu o często stosowane szeregi Deane'a i Cole'a (choć jak wszystkie dane z tego okresu są w pewnym zakresie dyskutowane; co także oddają ostatnie wersy). Ostatnia kolumna pokazuje, jak niewielki udział $\mathrm{w}$ dochodzie narodowym miały zyski czerpane z niewolnictwa. Co więcej, druga seria dobrze przedstawia, że wartość dodana spowodowana rewolucją przemysłową nie była generowana dzięki przemysłowi niewolniczemu.

Skąd zatem sława tezy Williamsa? Przede wszystkim z błędnego pojmowania akumulacji kapitału i roli, którą w rozwoju może odegrać dana branża. Powiedzmy, że ktoś zainwestował milion funtów w handel niewolnikami, a po pół roku upłynnił całość inwestycji, nie otrzymując ani funta więcej niż zainwestował. Czy można traktować taką osobę jako beneficjenta systemu niewolniczego? W pewnym stopniu tak, gdyż kapitał został przez ten czas zakonserwowany (choć de facto poniesiono na nim ekonomiczną stratę). Czy można jednak wyciągać wniosek, że w ten sposób niewolnictwo pozwala akumulować kapitał? Z pewnością nie.

Głównymi beneficjentami otrzymującymi zyski ekonomiczne z już utrwalonego systemu niewolniczego są przede wszystkim łowcy niewolników, a nie ich późniejsi posiadacze (Thomas, Bean 1974, s. 914). W rozpowszechnionym i utrwalonym systemie niewolnictwa posiadacz niewolników osiąga „standardowe” stopy zwrotu nieróżniące się specjalnie od stóp zwrotu z innych branży. Wyjątkiem jest sytuacja, gdy niewolnictwo dopiero się rozwija. Wtedy kupujący niewolników mogą nabywać ich po niskich cenach i sprzedawać po wyraźnie wyższych — osiągając wysokie zyski i przez to akumulując kapitał. W przypadku wieku osiemnastego - a więc kiedy niewolnictwo było już rozpowszechnione, a rynki przerzutu 
wyeksploatowane — trudno mówić o takiej sytuacji. Analizując czynniki podażowe i popytowe, musimy dojść do wniosku, że nie istniał monopson - niewolnicy byli kupowani z różnych stron świata przez różnych odbiorców, dlatego ich cena nie mogła być szczególnie niska. Istniał także element podażowy — wbrew pozorom pozyskiwanie niewolników przez białych najeźdźców nie odbywało się przy oporze całej lokalnej ludności. Niestety, niejednokrotnie lokalni kacykowie afrykańscy byli uwikłani w relacje handlowe z późniejszymi właścicielami niewolników, np. sprzedając jeńców pozyskanych po wojnach plemiennych (Ashton 1959, s. 157)². Gdy dodamy do tego inne koszty działania w niewolnictwie — inwestycje w statki, personel więzienny, ryzyko buntu i chorób — to okaże się, że wcale nie był to wysoce opłacalny biznes. Abstrahując, rzecz jasna, od samej haniebności owych czynów: włączanie się w handel niewolnikami w drugiej połowie wieku osiemnastego przypominać mogło przyłączanie do gorączki złota w końcowej jej fazie: wszelkie nadzwyczajne zyski już dawno zostały skapitalizowane i zrealizowane.

Oczywiście nie przeczy to $\mathrm{w}$ żadnym razie tezie, że w Lancashire istniały jednostki, które w momencie pojawienia się rewolucji przemysłowej mogły przenieść swoje aktywa z branży niewolniczej do branży przemysłowej. To jednak nie zmienia faktu, że imperialne zyski z niewolnictwa były relatywnie niewielkie, jak również temu, że zakres tych zysków nie mógł być siłą napędową brytyjskiej akumulacji kapitałowej (Drescher 1987, s. 190).

\section{System bankowo-finansowy a akumulacja kapitału}

Cechą charakterystyczną pierwszej fali rewolucji przemysłowej była wewnętrzna akumulacja kapitału, opierająca się na reinwestowaniu zysków i korzystaniu ze wcześniej zgromadzonych (np. rodzinnych) oszczędności. W pierwszej fazie nie możemy mówić o istnieniu rozległych rynków kapitałowych czy też systemu bankowego. Rynek finansowy i bankowy tak naprawdę rozwinął się znacząco już po rozpoczęciu samej rewolucji. Można nawet powiedzieć, że pierwotny londyński system bankowy, opierający się na założonym w 1688 Bank of England, był oderwany od pozostałej części systemu pieniężnego. W zasadzie bank ten mógłby się równie dobrze nazywać Bank of London ze względu na ograniczony zakres realizowanych transakcji. Między innymi z tych powodów zaczęły z czasem poza centrum Anglii rozwijać się country banks, zajmujące się obsługą parabankową. Co więcej, w pierwszym okresie funkcjonowania były to banki opierające się na spółkach osobowych, gdyż monopol na spółki kapitałowe przysługiwał nielicznym (Ashton 1959, s. 179, 183).

2 Fage (1969) próbuje odpowiedzieć na pytanie, do jakiego stopnia zewnętrzny popyt na niewolników gruntownie przeobraził społeczeństwa afrykańskie na poziomie politycznym, kulturalnym i demograficznym. W istocie wydaje się, że to właśnie na tym gruncie przemysł niewolniczy dokonał istotnego spustoszenia. 
Budowanie rewolucji przemysłowej na samodzielnej działalności i spółkach osobowych zdecydowanie ograniczyło jej pozytywny wpływ. Bez ograniczonej odpowiedzialności trudno sobie wyobrazić głęboko rozwinięty rynek inwestycyjny. Możliwość zakładania spółek akcyjnych z jednoznacznie określoną ograniczoną odpowiedzialnością była dopiero wynalazkiem wieku dziewiętnastego. Także wtedy pojawia się kolejna już dużo bardziej znacząca fala rewolucji przemysłowej. Wcześniejsza faza wzrostu charakteryzowała się w zasadzie brakiem wszechstronnego rynku finansowego (Trew 2010, s. 987-988). Spółki akcyjne, swobodnie zakładane przez wszystkich, pozwalają mobilizować kapitał wielu oszczędzających, którzy nie chcą ponosić większego ryzyka niż własny wkład do spółki. Dla głębszego rozwoju rynku i produkcji architektura finansowa jest kamieniem milowym, ponieważ istnienie rynku płynnych instrumentów finansowych (i mniej ryzykownych) pozwala na znaczące mobilizowanie oszczędności i inwestycji (Levine 2004, s. 17). Historycznie patrząc, można zaryzykować tezę, że to zmiany gospodarcze i rewolucja przemysłowa wywarły „presję" na to, aby spółki kapitałowe stały się powszechnym sposobem mobilizowania kapitału, a nie jedynie zarezerwowanym dla wybranych, tak jak to miało miejsce na początku.

Wcześniej przedsiębiorcy byli skazani na brak dostępu do wyrafinowanych narzędzi finansowania. Heaton (1937) przeanalizował przykładowo sławny przemysł wełniany w Yorkshire, który pozyskał środki na różne sposoby — zdarzało się wsparcie handlarzy, właścicieli ziemi (wynajętej do produkcji); wsparcie banków było minimalne, gdyż bankowość inwestycyjna rozwinęła się dosyć późno. Najbardziej istotnym źródłem pozostawały osobiste i rodzinne oszczędności. Wraz z nimi ważkimi elementami były wspomniane spółki osobowe (Heaton 1937, s. 5-6). Jednocześnie warto pamiętać o dynamicznym rozwoju wspomnianych country banks, które emitowały papiery wartościowe, obsługujące transakcje między kontrahentami (Hudson 1981, s. 380). Oznaczało to w rzeczywistości bardzo szybkie kiełkowanie rynku finansowego, który wraz z nadejściem ograniczonej odpowiedzialności pozwolił na jeszcze większy wzrost gospodarczy. Brunt (2006, s. 96) wskazuje na to, że country banks w zasadzie bardziej przypominały proto-venture capital niż proto-banki. Niejednokrotnie gromadzono w nich kapitał od konkretnych większych inwestorów po to, aby w dużej mierze zainwestować go w wiadome ryzykowne przedsięwzięcia. $\mathrm{Z}$ tego powodu country banks mają niewiele wspólnego ze współczesnymi bankami, prowadzącymi rachunki oszczędnościowo-rozliczeniowe.

Rozproszonym i mało wyrafinowanym formom finansowania - bez rozbudowanego systemu giełdowego i ograniczonej odpowiedzialności - sprzyjał fakt, że wiele inwestycji nie wymagało ogromnych nakładów na koszty stałe (Pollard 1964, s. 300-301). A skoro koszty stałe nie były ogromne, to konieczne stało się finansowanie głównie kosztów zmiennych, które łatwo powiązać ze sprzedażą i akumulacją wewnętrzną bez polegania na kapitale z zewnątrz. Po części to również współgra z faktem, że struktura produkcji w początkach rewolucji przemy- 
słowej była relatywnie rozproszona i prowadzona przez mniejsze podmioty. Znacząca koncentracja i budowa wielkich fabryk, korzystających z efektów ekonomii skali, następuje w zasadzie dopiero bliżej połowy dziewiętnastego wieku, choć nawet po jej wystąpieniu ciągle istniały małe rozdrobnione podmioty, opierające się często na samozatrudnieniu (Hudson 2004, s. 37). Także w późniejszym czasie wzrost gospodarczy przynosi większe owoce produkcji w postaci rosnącego dobrobytu mas $^{3}$. Trudno nie wiązać tego $\mathrm{z}$ rozwinięciem rynków finansowych mobilizujących kapitał w znacznie szerszym i lepszym zakresie niż miało to miejsce wcześniej. Szczególnie, że zwiększony wzrost następuje wraz ze stopniową liberalizacją prawa w zakresie tworzenia spółek (Newton 2010, s. 47).

Jednocześnie warto pamiętać o tym, że system bankowy w Wielkiej Brytanii był mniej aktywny inwestycyjnie niż np. w Niemczech (Tilly 1989, s. 196). Oczywiście, nie należy ówcześnie rozwijającego się rynku finansowego i bankowego traktować jako ideału. Dużo elementów pozostawiało wiele do życzenia. Nie zmienia to jednak faktu, że okres rewolucji przemysłowej był jednym z najmniej inflacyjnych okresów w Wielkiej Brytanii, zwłaszcza na tle poprzednich wieków charakteryzujących się psuciem monety (Ashton 1959, s. 199).

\section{Zarzuty o merkantylistyczne elementy gospodarki brytyjskiej}

Gospodarka Wielkiej Brytanii była daleka od w pełni leseferystycznego porządku. W niektórych okresach i branżach aparat państwowy pozostawał niezwykle aktywny. Natomiast efektywność owego aktywizmu pozostaje wysoce dyskusyjna.

Przykładowo, Philip Coelho zestawił uproszczoną analizę kosztów i korzyści kolonializmu, obejmującą dochody rządowe w porównaniu do wydatków konstrukcyjnych i militarnych (uwzględnił też koszty po stronie konsumentów, m.in. wyższe ceny cukru aniżeli np. na rynkach amsterdamskich, spowodowane obciążaniem konkurencyjnych importerów). Uproszczona analiza wskazuje na to, że kolonie indyjskie były kosztem netto. W tym momencie na usta ciśnie się pytanie: dlaczego w takim razie kolonie w ogóle utrzymywano, skoro były nieopłacalne? Pytanie to musi zostać zadane tylko wtedy, gdy potraktujemy rządy jako realizatorów optymalnych społecznie rozwiązań. W praktyce jednak działania rządów są niejednokrotnie ucieleśnieniem lobby — i tak było w tym wypadku. Głównymi beneficjentami była wąska grupa właścicieli plantacji. Uzyskiwali oni wyższą cenę cukru i jednocześnie militarną ochronę. Ze względu na oligarchiczną strukturę rządową łatwo mogli korumpować urzędników i jednocześnie przerzucać koszty na pozostałe osiem milionów Brytyjczyków płacących podatki i wyższe

${ }^{3}$ Dyskusja historyków w kwestii (istnienia lub braku) wzrostu dobrobytu społeczeństwa dotyczy w zasadzie okresu do pierwszego kwartału wieku dziewiętnastego. Nikt w sumie nie kwestionuje ogromnego wzrostu dobrobytu w późniejszym okresie. 
ceny za towar (Coelho 1973, s. 278-280). Stanowi to klasyczny przykład pułapki szkoły wyboru publicznego, pokazującej, że kolonializm uderzał nie tylko w kolonie, lecz także w społeczeństwo pod okupacją rządu narodowego. Jak to zresztą niejednokrotnie przy interwencji państwa bywa.

Podobne, choć niewątpliwie szczątkowe analizy możemy zastosować do sławetnych aktów nawigacyjnych, które stanowiły protekcyjny wynalazek chroniący wąską grupę producentów. Mimo że danych mamy zdecydowanie zbyt mało, to te, które są dostępne, wskazują przede wszystkim na efekt redystrybucyjny aktów nawigacyjnych — podnoszenie zysków w jednej branży kosztem zysków w innej (Hausman 1977, s. 473). Nie inaczej było z długiem publicznym, który w trakcie rewolucji przemysłowej (tak jak i dzisiaj) wywoływał efekt wypychania. Oznacza to, że znaczące brytyjskie zadłużenie państwa (szczególnie w trakcie wojny) nie było wielkim błogosławieństwem dla gospodarki, a przeciwnie - uderzało w prywatną akumulację kapitału i zmniejszało rzeczywisty wzrost produkcji (Black, Gilmore 1990, s. 130-131). Potwierdzają to też badania dotyczące inflacji w wieku osiemnastym. Przykładowo, w okresach rosnących cen po 1790 roku zależność między rosnącą inflacją a długiem publicznym jest szczególnie uderzająca. Jak pokazuje Elizabeth Schumpeter (1938, s. 31), wzrost cen wystąpił szczególnie w tych wojennych latach, gdy radykalnie rosło zadłużenie państwa i wiążąca się z tym inflacja pieniądza.

Nowa wartość ekonomiczna w gospodarce brytyjskiej była generowana w mechanizacji i pomysłowości krajowych przedsiębiorców. Oznacza to także, że handel zagraniczny - choć niewątpliwie korzystny - nie był główną siłą napędową przemian ekonomicznych. O'Brien (1982, s. 17) przeanalizował zyski i obroty powiązane z peryferiami i wskazał, że gdyby Wielkiej Brytanii zakazać handlu z peryferiami imperium, to całkowite wydatki inwestycyjne brutto spadłyby o nie więcej niż 7\%. Dodajmy przy tym, że jego konkluzje można by zdecydowanie wzmocnić obserwacją, iż przecież nominalne wydatki inwestycyjne jako procent osiąganych dochodów nie były w gruncie rzeczy przyczyną eksplozji produktywności. Zmiana była ja k ości o wa, a nie ilościowa. Wynikała nie z konkretnego, np. podniesionego poziomu inwestycji per se, lecz in w e s ty cj i w nowe rozwiązania

Skoro jesteśmy już przy międzynarodowym handlu, to warto pamiętać, że nawet on nie mógł stanowić kwintesencji i źródeł przemysłowej rewolucji. To raczej rewolucja przemysłowa spowodowała zwiększenie roli handlu międzynarodowego - pozwala bowiem na dyfuzję nowych produktów na światowe rynki. Przyjrzymy się analizie Crouzeta, pokazującej w jakiej części eksport odpowiadał za brytyjską produkcję (1980, s. 78):

${ }^{4}$ To z kolei thumaczy inną kwestię, której tu nie wyjaśniamy — doszło do rewolucji gospodarczej i przedsiębiorczego przełomu, mimo że nie podniosła się np. radykalnie skłonność do oszczędzania. 
Tabela 3. Wielkość brytyjskiego eksportu w porównaniu do dochodu narodowego

\begin{tabular}{c|c|c|c}
\hline Rok & $\begin{array}{c}\text { Dochód narodowy } \\
\text { (miliony funtów) }\end{array}$ & $\begin{array}{c}\text { Eksport } \\
\text { (miliony funtów) }\end{array}$ & $\begin{array}{c}\text { Udział eksportu } \\
{[\%]}\end{array}$ \\
\hline 1688 & 48 & 4 & 8,3 \\
\hline 1700 & 58,5 lub 52 & 4,4 & 7,5 lub 8,5 \\
\hline 1759 & 85 & 9,9 & 11,6 \\
\hline 1779 & 130 & 9,9 & 7,6 \\
\hline 1783 & 160 & 12,4 & 7,8 \\
\hline 1801 & 232 & 41,4 & 17,8 \\
\hline
\end{tabular}

Przez kolejne kilkadziesiąt lat eksport brytyjski stanowił kilkanaście procent produktu narodowego, zdecydowanie bliżej 10\%. Dopiero po 1861 roku eksport przekroczył barierę 20\% (abstrahując już od faktu, że kwitnące rynki były głównie związane z gwałtownie rozwijającą się Europą Zachodnią i Stanami Zjednoczonymi, a nie koloniami). Zresztą nie bez przyczyny, skoro przemysł brytyjski stał się w wielu sektorach najlepszym i najbardziej efektywnym na całym świecie. Wcale nie dlatego, że po świecie pływały brytyjskie statki, które pod groźbą armaty kazały kupować brytyjskie produkty.

Przy obserwacji owych statystyk pamiętajmy, że w tamtym czasie nie istniały dokładne kontrole rządowe, w związku z czym całkowicie zasadne jest założenie, że eksport bywał przeszacowany (a import niedoszacowany).

\section{W poszukiwaniu źródeł rewolucji przemysłowej}

Trudno zaprzeczać istnieniu wielu wymienionych już negatywnych elementów gospodarki brytyjskiej, jednakże samo ich wystąpienie nie oznacza jeszcze bycia siłą napędową rewolucji przemysłowej. Gdzie zatem można szukać przyczyn dla ogromnej przemiany, dla zbudowania czegoś, co Joel Mokyr nazywa „oświeconą gospodarką"? Hipotez pozwalających na ich odnalezienie jest kilka, a w zasadzie jest kilka znaczących czynników, które zauważają historycy. W tym artykule nie chcę podejmować się definitywnej odpowiedzi, lecz warto zwrócić uwagę na to, czym w ogóle była rewolucja przemysłowa. Proste pytanie dające trywialną choć niekoniecznie fundamentalną — odpowiedź jest jednocześnie dodatkowym argumentem podważającym hipotezy imperialno-merkantylistyczne.

Otóż rewolucja przemysłowa była okresem gigantycznej implementacji przedsiębiorczych innowacji. Wynikała z pomysłowości wielu handlowców, kupców, przemysłowców, fabrykantów, którzy wprowadzali całą masę udoskonaleń, eksponencjalnie zwiększających produkcję. W tym właśnie Wielka Brytania zaczęła przodować nad resztą świata. Jeśli rozpatrujemy konkretne przypadki wielkich sukcesów, to obraz staje się klarowny. Przykładowo, przemysł produkujący 
kapelusze stał się ogromnym eksportowym hitem, ponieważ zastosowano mechanizację pozwalającą na jednoczesne farbowanie materiałów. Znacznie szybsze aniżeli we wcześniej realizowanych ręcznych metodach. Przemysł papierniczy stał się gigantyczny, gdyż zaczęto wytwarzać papier znacznie szybciej i znacznie sprawniej za pomoca produkowanych dla zysku maszyn. Benjamin Gott stał się największym na świecie producentem wełny — dzięki wprowadzeniu chemicznych udoskonaleń zdołał osiągnąc ogromne korzyści ekonomii skali i przez to znacząco przebić swoich konkurentów (Wilson 1957, s. 107).

Dyfuzja mechanizacyjnych rozwiązań stosowanych w różnych branżach przypominała memy. Możemy to też dostrzec w sławetnej innowacji w rolnictwie, polegającej na wprowadzeniu młocarni, zastępującej duże zatrudnienie siły roboczej. Zwróćmy uwagę na porównanie zastosowania maszyny w poszczególnych regionach w roku 1794 i 1808:

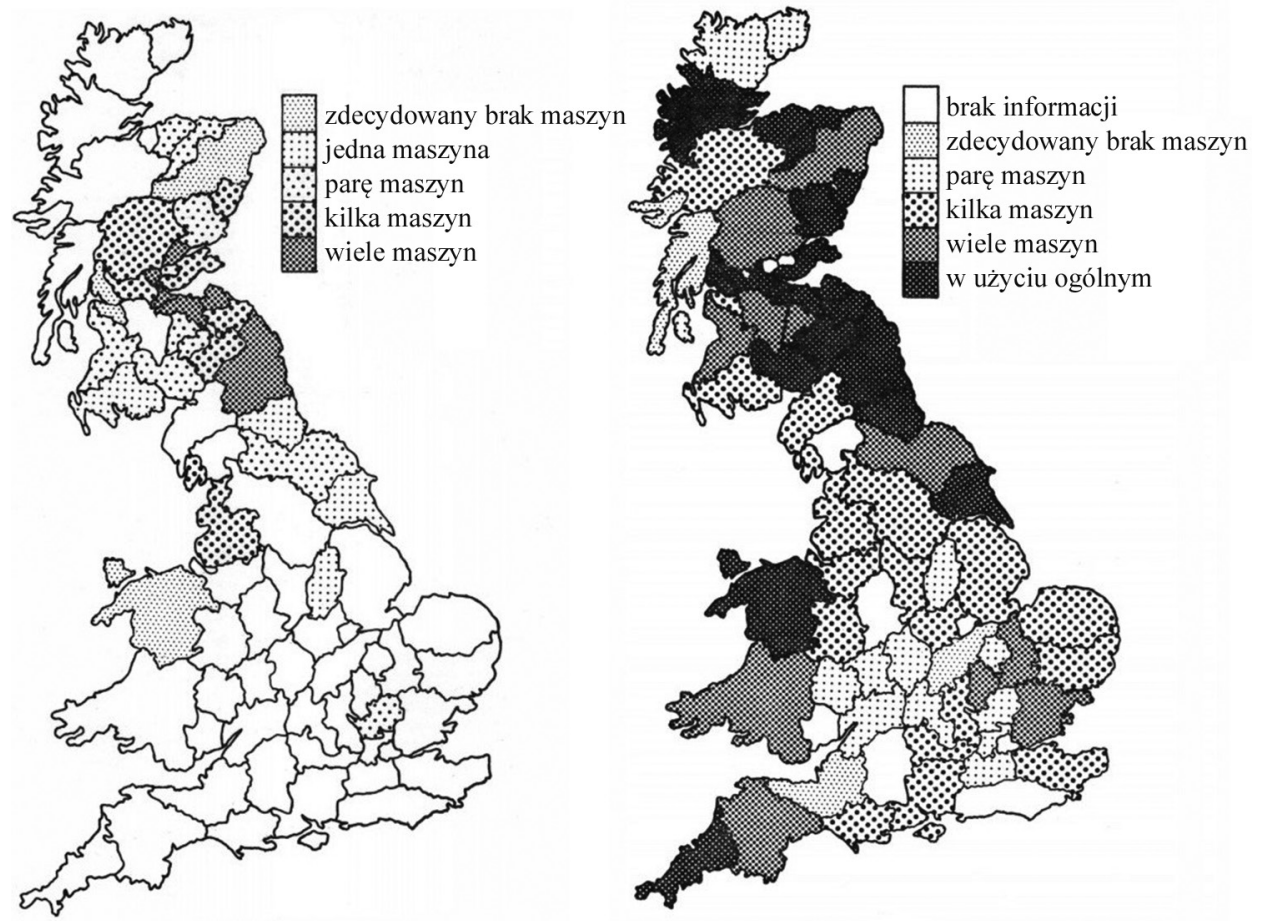

Rysunek 1. Zastosowanie młocarni w roku 1794 (lewa strona) i 1808 (prawa strona)

Źródło: MacDonald 1974, s. 68-69.

W 1794 roku mało regionów posiadało wiele maszyn. Niektóre z nich miały kilka. W ciągu 14 lat doszło do znaczącego rozprzestrzenienia się tychże maszyn (zapewne $\mathrm{w}$ wyniku bezpośrednich inspiracji, wymiany idei, a także podglądania innych). W efekcie, w 1808 roku, mamy już regiony, w których maszyny są 
w powszechnym lub częstym użyciu, a tylko kilka regionów pozostaje w tyle ${ }^{5}$. $\mathrm{W}$ ten sposób doszło do rewolucyjnej przemiany w brytyjskim rolnictwie. W tym samym czasie przeważająca część świata pozostaje daleko w tyle.

Podobnie moglibyśmy opisać wszystkie pozostałe inwencje po stronie przedsiębiorców, które wprowadzano w życie. Na tym właśnie polegała rewolucja przemysłowa i z tego się wzięła, a w zasadzie tym właśnie była.

\section{Podsumowanie}

Analizy historii gospodarczej zawsze wywołują spory i kontrowersje, ponieważ doświadczenia ekonomiczne charakteryzują się współwystępowaniem wielu sprzecznych czynników. Jedynym rozwiązaniem jest skrupulatna i przemyślana analiza teoretyczna, uwzględniająca rzeczywistą wagę empirycznych uwarunkowań. Tak też powinno być w wypadku opisu zjawiska rewolucji przemysłowej, która wystąpiła w otoczeniu pewnych form imperializmu i etatyzmu. Otoczenie rewolucji nie było jednakże zawężone tylko do tych czynników. W świetle tego, że istniały one przez lata — zarówno w brytyjskim, jak i innych systemach przyczyn jej wystąpienia musimy szukać w innych dużo bardziej obiecujących hipotezach.

\section{Bibliografia}

Anstey R.T. (1968), Capitalism and Slavery: A Critique, „The Economic History Review. New Series" 21, nr 2.

Ashton T.S. (1959), An Economic History of England: The 18th Century, London.

Black R.A., Gilmore C.G. (1990), Crowding Out during Britain’s Industrial Revolution, „The Journal of Economic History" 50, nr 1.

Brunt L. (2006), Rediscovering Risk: Country Banks as Venture Capital Firms in the First Industrial Revolution, „The Journal of Economic History” 66, nr 1.

Coelho P.R.P. (1973), The profitability of imperialism: The British experience in the West indies 1768-1772, „Explorations in Economic History” 10, z. 3.

Crouzet F. (1982), Toward an Export Economy: British Exports During the Industrial Revolution, „Explorations in Economic History” 17, z. 1.

Crouzet F. (2008), The First Industrialists. The Problem of Origins, Cambridge.

Drescher S. (1987), Eric Williams: British Capitalism and British Slavery, „History and Theory” 26, nr 2.

Engerman S.L. (1972), The Slave Trade and British Capital Formation in the Eighteenth Century: A Comment on the Williams Thesis, „The Business History Review” 46, $\mathrm{nr} 4$.

Fage J.D. (1969), Slavery and the Slave Trade in the Context of West African History, „The Journal of African History" 10, nr 3.

Hausman W.J. (1977), Size and Profitability of English Colliers in the Eighteenth Century, „The Business History Review" 51, $\mathrm{nr} 4$.

5 Szacunki MacDonalda również są przedmiotem dyskusji (MacDonald 1978). Jednakże w tym miejscu nie chodzi o same dokładne dane, lecz o ogólną zasadę gospodarczej ewolucji. 
Heaton H. (1937), Financing the Industrial Revolution, „Bulletin of the Business Historical Society" $11, \mathrm{nr} 1$.

Hudson P. (1981), The Role of Banks in the Finance of the West Yorkshire Wool Textile Industry, c. 1780-1850, „The Business History Review” 55, nr 3.

Hudson P. (2004), Industrial organisation and structure, [w:] The Cambridge Economic History of Modern Britain. Volume 1: Industrialisation, 1700-1860, red. R. Floud, P. Johnson, Cambridge.

Levine R. (2004), Finance and Growth: Theory and Evidence, NBER Working Paper No. 10766, Issued in September 2004.

MacDonald S. (1974), The Progress of the Early Threshing Machine, „The Agricultural History Review" 23, nr 1.

MacDonald S. (1978), The Further Progress with the Early Threshing Machine: A Rejoinder, „The Agricultural History Review” 26, nr 1.

Newton L. (2010), The Birth of Joint-Stock Banking: England and New England Compared, „The Business History Review” 84, nr 1.

O'Brien P. (1982), European Economic Development: The Contribution of the Periphery, „The Economic History Review. New Series" 35, nr 1.

Pollard S. (1964), Fixed Capital in the Industrial Revolution in Britain, „The Journal of Economic History" 24, nr 3.

Schumpeter E.B. (1938), English Prices and Public Finance, 1660-1822, „The Review of Economics and Statistics" 20, $\mathrm{nr} 1$.

Thomas R.P., Bean R.N. (1974), The Fishers of Men: The Profits of the Slave Trade, „The Journal of Economic History" 34, nr 4.

Tilly R.H. (1989), Banking Institutions in Historical and Comparative Perspective: Germany, Great Britain and the United States in the Nineteenth and Early Twentieth Century, ,Journal of Institutional and Theoretical Economics (JITE) / Zeitschrift für die gesamte Staatswissenschaft" $145, \mathrm{nr} 1$.

Trew A. (2010), Infrastructure Finance and Industrial Takeoff in England, „, Journal of Money, Credit and Banking" 42, nr 6.

Wilson C. (1957), The Entrepreneur in the Industrial Revolution in Britain, „History” 42, nr 145.

Ekonomia - Wroclaw Economic Review 23/2 (2017)

(C) for this edition by CNS 